\title{
Women and Sufism in South Asia: A Survey of Historical Trends
}

\author{
Saad Ali Khan ${ }^{1} * \&$ Abida Bano ${ }^{2}$ \\ 1. Centre of Excellence in Gender Studies, Quaid-i-Azam University, Islamabad, Pakistan. \\ 2. Institute of Peace \& Conflict Studies, University of Peshawar, Peshawar, Pakistan.
}

\begin{abstract}
The historical evidence suggests that women and men have been considered equal in the path of Tasawuff (Sufism). However, there are few studies that documents and analyse women's presence in South Asian Sufism. This "hagiographical silence" (historically) about Sufi women in South Asia raises questions and needs scholarly attention to address the gaps in the literature. The article explores some of the trends present and related to women and Sufism in South Asia in the existing literature. Drawing on historical sources (secondary material) and employing thematic analysis, the article examines significant trends in women and Sufism in South Asia. These multiple trends include lack of historical evidence, less documentation about Sufi women, paradoxical imagination about women, and gendered roles, all of which point out to the specific context and history of South Asian Sufi culture. The paper problematizes the assumption that Sufism (in general) has been open, inclusive, and accommodative to women and issues of gender. This study also analyses the data and the historical context of how women have been imagined and treated within South Asian Sufism. However, this research is not constructing any generalization and is presenting the analysis within a specific historical and cultural context South Asia.
\end{abstract}

Keywords: Women Sufis, Sufism, South Asia, Gender, Historical Trends, Hagiographical Silence, Tasawuff, Sufi Literature.

\section{Introduction}

Nizam-ud-Din Auliywa (Mehbub-i-Elahi) - a $13^{\text {th }}$ century Sufi, is reported saying, "when the lion comes out of the forest, nobody asks whether it is a male or a female. The progeny of Adam should aspire to piety and sanctity whether they are men or women." This saying is being recorded in Akhbar al-Akhyar fi Asraral-Abrar, a copious compendium by Muhaddis Dihlawi in the section of pious (Sufi) women of South Asia. Akhbar al-Akhyar is considered one of the best tabaqat ${ }^{1}$ (Sufi literature) produced in South Asia. The history of Sufism in South Asia has been thoroughly researched and well documented by different scholars. Many scholars (insiders and outsiders - as conceptualized by historian Alexander Knysh, 2017) have produced significant studies exploring, describing, and analysing Sufism's history in South Asia. New and exciting trends have emerged in both academic and non-academic literature lately. Among these, gender and woman aspects have now gained much of the academic world's attention. More research and studies explore the role, presence, or absence thereof women in Sufism in contemporary times. However, there is a dearth of literature on Sufi women in specific contexts, such as South Asia, for its specific culture and history. 
Women's presence within Sufism, as argued, can be fully observed from the earliest times, especially from the seventh to tenth centuries. There is ample historical evidence (more studies are dedicated to this issue more recently) that demonstrated how women during this period remained visible and active within Sufism. One of the most oft-cited Sufi women, Rabia alAdawiyya (d. 801), also belonged to the same time. Most of the debates and much of the literature on Sufi women are mostly focused on Rabia al-Adwiyya (Azad, 2003: 54). Historically, Sufism is also known as the pre-institutional phase (pre-tariqa Sufism), where no formal Sufi silsilas ${ }^{2}$ existed. This formative period of Sufism was attributed to the ideas and practices of Sufis of their respective times. Rabia al-Adawiyya, as a Sufi woman, became an archetype for the rest of the individuals, especially for women of all times. She has been attributed as the first Sufi who has introduced the concept of unconditional love for the Divine - a radical shift in Sufi thought and practice that has inspired many generations of Sufis to come (Schimmel, 2019).

Women have always participated and remained part of South Asian Sufism (Tasawuff) ${ }^{3}$ has now been accepted and least contested. Far from contestation, some of the scholars maintained that Sufism not only offered more space to women, but it is also generally more accommodative. Some scholars have even compared and contrasted Sufism with Islam (more puritanical) and argued that Sufism is more gender-egalitarian and gender-sensitive than women's questions. However, such conclusions and observations are reductive and fixate on certain forms of imagination, generating essentialist claims. Women's place within Sufism is often compared (historically and even in contemporary times) with women's position in Islam, pitting both Sufism and Islam against each other, depicting the former (Sufism) as more liberal than the latter (Islam). However, such positioning tends to obscure the social reality more than it reveals about it. Cautioning against such comparisons, Sharify-Funk et al. argue that "these popular understandings in the contemporary context tend to presume essential oppression of women in Islam, and an elevation of women in Sufism, which further polarizes Sufism and its relation to Islam" (2017: 213). The Encyclopedia of Muslim women and cultures aptly presents this aspect in these words:

Images of sex, gender, and women in Sufism are complex, comprised of equitable, beautiful, and misogynistic depictions often derived from the same cosmological gender images. These images are problematic precisely because the same issues in the wider Muslim society are complicated. The whole of the Sufi statements must be considered in their historical and interpretative contexts to adequately access the nature of the positions taken and their influence on later Sufism (Silvers, 2014: 539).

The presence of Women and participation within Sufism in practice is more complex and required historicizing with contextual understanding. As mentioned by Sharify-Funk et al. (2017) "considering the status of women within Sufi and Muslim contexts is not simply a matter of marginalization or "empowerment," but is far more nuanced, as women negotiate and occupy a spectrum of the sphere in their enactment of Sufi traditions (213)." Similarly, Shaikh (2012) argued that Sufism neither presents a monolithic position on gender nor "a historical panacea for all things beneficial for women (72)." Reflecting upon the role and position of women within Muslim societies, Schimmel (2003) conversely observed an overall decline rather than deterioration in the situation. She maintained that women continue to play a significant role in Sufism in the Muslim world. Tracing women's presence in the history of Sufism, she concluded: 
The Islamic image of pious women dedicated to an ascetic and mystical life is a colourful one, for it includes strict ascetics as well as women scholars, noblewomen who maintained an interest in religious works even amid the duties of country life imposed upon them, simple girls or old women whose names only vaguely hint at their mystical experiences but who confronted and consoled thousands of women down through the centuries via their Baraka, their "blessings" or "power of sanctity"...the image of a saintly woman thus holds a particular significance for Muslim women who frequently turn to their sisters, be they living or long since dead, for comfort and consolation. (Schimmel, 2003: 53).

The history of Sufism (in general) demonstrates that many women have played an active role in all aspects of the Sufism. Women have been recognized as teachers, mentors, guides, students, disciples, seekers, and aspirants of this path (Dakake, 2002; Buehler, 2016). Although there has been a paucity of literature on Sufi women's lives in history, some names of women have been prominent for their remarkable contributions to the thought and activity of Sufism (Smith, 1928). Foremost among those is Rabbiya al Adawiya (d. 801), who has been recognized as the first Sufi who introduced the concept of "unconditional love" in Sufism. The history reveals that she was known for her piety and love for the Divine and her gnosis of the path. She used to give public sermons on the mysteries of the Sufi path. There have been many male Sufis of her time who have benefited from her discourses (Smith, 2001). Her anecdotal interactions with great Sufi Hassan Basri (d. 728) marked interesting development within Sufism's initial history as a Sufi leader. Women's roles within Sufism, as assumed, have not been limited to their social roles of being mothers, wives, sisters, and daughters. During the medieval period of Sufism, many Sufi women were recognized as teachers of their times. Ibni-Arabi (d. 1240), also known as Shaykh-e-Akbar (the grand shaykh), shared his own spiritual teaching experience with two Sufi women. He regarded both these Sufi women with high respect and considered them his teachers (Shaikh, 2012). Exclaiming one of his Sufi woman teachers, he said:

In her spiritual activities and communications, she was among the greatest. She had a strong and pure heart, noble spiritual power, and subtle discrimination and endowed with many graces. I had considerable experience of her intuition and found her to be a master in this sphere. Her spiritual state was characterized chiefly by her fear of God and His good pleasure in her, combining the two simultaneously in one person being scarce among us (Austin, 2007: 142).

In recent years, there is a growing body of literature throughout the world that has taken up women and gender in Sufism. With more studies produced throughout the world, it has started a new wave of scholarship exploring, analyzing, and discussing women and Sufism. Various aspects of this topic have been explored, including the rise, presence, role, and work of Sufi women (like, Callan, 2008; Flueckiger, 2006; Frede \& Hill, 2014; Gemmeke, 2009; Hill, 2010, 2014, 2018; Kakkar, 2006; Kasmani, 2016; Kim, 2009; Nurbakhsh, 2004; Raudvere, 2002; Shafiq \& Rehman, 2018; Shaikh, 2012; Silvers, 2014; Tryckeri \& Schielke, 2008; Widiyanto, 2014). Scholars (like, Pemberton, 2016; Ernst, 2009) working on the issue have argued that due to transformation in Sufism (structural and discursive), more and more women are taking up positions of authority and leadership that were previously reserved for men, which resulted in a rise of Sufi women shaykhs all over the world. ${ }^{4}$ Analyzing the role of women in the history of Sufism, some scholars have also argued that, "While institutions and literature about Sufism 
tended to amplify men's voices, women actively participated in Sufi culture and practice-albeit, often within the socially sanctioned roles of their times."

To Ernst (2003), the increased participation of women in Sufism around the world today is also a consequence of global changes in women's roles. For him, the area of gender relations is indeed the most striking recent development within Global Sufism. Simultaneously, Sufi tariqas at the Global level have undergone structural changes over the period, becoming more gender-inclusive. For scholars like Ernst, women's presence and participation point to a change in Global Sufism, even a new beginning, what he called "feminist interpretations of Sufism" (Ernst, 2003). However, for scholars like Pemberton, Sufism has undergone "structural and symbolic changes" that fundamentally paved the way for more women to participate within Global contemporary Sufism (Pemberton, 2016). She noted that inclusivity and progressive mindedness positively impacted the social world of activity and brought more women within the activity realm.

It has been established that many scholars have dedicated their work to analyse several significant aspects of Sufism. Nevertheless, there are gaps and spaces in the literature yet to be filled - the present research work endeavours to highlight those spaces and engage with more plausible explanations. In so doing, the paper problematizes the given assumption that Sufism (in general) has been open, inclusive, and accommodative to women and issues of gender. Moreover, it also critically analyses the data and the historical context of how women have been imagined and treated within South Asian Sufism. However, in no way is this research constructing any generalizations and is only presenting the analysis within a specific historical and cultural context - South Asia.

\section{Research Methodology and Data Sources}

This article has employed a qualitative research methodology to address the issue at fore. The research is exploratory and descriptive in nature and has relied on rich secondary resources (historical) to document the trends related to the issue at hand. These secondary resources included both published and unpublished material in the forms of manuscripts, books, and articles (journals and magazines). The article presents a survey of historical trends related to Sufi women in South Asia. Thus, the studies that speak to the issue directly or indirectly make a part of the study.

This research draws on interpretative approaches, wherein meanings and interpretations of social reality are constructed in a specific social and political context. Thus, the facts are fluid and embedded within a system of meanings that are not impartial, objective, and neutral. Based on secondary data resources, various trends have been identified through thematic analysis to understand the issue. The thematic analysis provided a better conceptualization of the historical trends present and identified in the collected data. It also aids in analysing, interpreting, and conceptualizing "patterns" 5 and central themes in the qualitative data.

Additionally, it helps in exploring implicit and explicit "meaning" embedded in data. Without generalizing and claiming an exhaustive work on the topic (that certainly requires more research and scholarly work), the present endeavour contributes to the more extensive academic debate on women/gender and Sufism. This paper contributes to the scholarly literature on South Asian Sufis and Sufism while focusing on women and gender in the historical context that is an understudied subject. 


\section{Important Themes and Analysis}

Historically, multiple trends show trajectory of the relationship between women and Sufism in the context of South Asia. They manifest the gender dynamics in South Asian society and demonstrate how these individuals have been imagined, situated, and evaluated. The following trends indicate women's connections with the Sufism in South Asia.

\subsection{Sufi Women - Veiled/Silenced in the Sufi Literature}

The first and foremost trend evident from the history is that there is less documentation of women and especially Sufi women in Sufi literature of South Asia. Some scholars termed this as "veiling or silencing" of women generally, while for others, this is related to society's particular culture that prevents discussion related to women. Interestingly, this observation is not peculiar to South Asian Sufism but can be seen and analysed in different parts of the world. One glaring example is the work of Rkia Cornel (1999) work, which aimed to reveal the "hagiographical ${ }^{6}$ silence" through Al Sulami's work. Analysing this historical fact, Ernst concluded that subtle misogyny exists in the Sufi texts (1997: 181). One could hardly find a detailed description and analysis of Sufi women's lives within many Sufi literature genres. Even if certain forms of literature do that, it almost obscures the reality of the person concerned. While many compendiums about Sufis (men) can be found, there is hardly any mentioning of women therein. For instance, Sufism's first Persian work in South Asia was Ali Usman Hajvari (Alias Data Gunj Bukhsh), known as Kahsf ul Mahjoob. It has detailed discussions on Sufis of South Asia, but he has not discussed even one woman as Sufi in South Asia.

Similarly, there are other manuals and compendiums that discussed Sufis but very few have discussed about women role as Sufis. Ernst (1997) noted that in most cases, women's biographies make a part of an appendix to men's biographies that are the "main"7 subject of the book. Similarly, Pande (2010) highlights the silencing of women in statist historiographical tradition in these words: "In the Indian context the literary elite were Brahmans, writing in Sanskrit, and later the Maulvis writing in Persian - both articulating a point of view that was not representing women."

Most of the hagiographies, biographies, and other forms of Sufi literature in South Asia document the Sufi men explicitly while veiling the subject of the women and Sufism. However, a few Sufis have transcended this norm of their times and have incorporated some Sufi women in their works on Sufism. Among these, the work of Abd al-Haqq Muhaddith's Reports of the Righteous on the Secrets of the Pious is worth mentioning. He has included the descriptions of $13^{\text {th }}$ century women who were associated with the Chishti Sufi order. Bibi Sara and Bibi Fatima's lives were given in detail. Even the historians of the later times only included a few entries on the Sufi women in their works. Rizvi's work on Sufism in South Asia mentioned female Sufis of South Asia as an annexure to the main work, arguing that "we have mentioned here only the most outstanding female Sufis amongst those whose lives have been documented however the biographies of a large number of saintly women remain unknown (1978: 405)."

It is evident from the historical sources that women in general and Sufi women, in particular, have found little space in Sufi literature of the times. The lack of documentation can be attributed to many issues in the context. For instance, veiling (Purdah) for the Muslim women can be considered a relevant factor that contributed to the erasure of women from the Sufis world. Similarly, it also points out how the Sufis (male) treated the women, especially in their 
Sufi orders. However, to argue with any certainty, the issue must be contextualized and linked to the time and space. Since many scholars and historians are now digging deep into the history to explore the connections, the expectation is, the complexity of the issue will be cleared through rare evidence. According to Scattolin (1993), the Sufi women remained historically a part of Sufism.

\subsection{Paradoxical Images of Women - Negative vs. Positive (Complementary and Contradictory)}

The data shows another paradoxical trend. On the one hand, women have been demonized and equated with sin and evil, while exalted some Sufi women, on the other. The historical trend shows that how the Sufis imagined and viewed women at times. Interestingly, through the Sufi literature, one can emphasize that diverse imaginations about women existed. These imaginations, held by the Sufis, strained with positive and negative values, also reflected in their society and the belief system. While some Sufis held great respect for the women, others have explicitly shared their reservations and concerns about their status and position within the Sufi orders.

Classical Sufi literature, prose, and poetry, in its various forms (tazkiras, malfuzat, rubaiyat, ghazals), yields diverse imagination about gender and women in general to the Sufi path. These understanding(s) are undoubtedly a by-product of the individual Sufi's engagement, understanding, and appropriation with the social world and seems to be a consequence of larger societal structures of particular time and context. Hence, classical Sufi literature both imbibe and reproduces the socio-cultural milieu of time and space. The Sufi literature is replete with such imaginations. At one level, women (in general) are equated with the $n a f s$ (soul/self/ego a feminine noun) inciting to evil (Schimmel, 2003: 20). Moreover, women on the Sufi path in specific are relegated to individual spaces and given certain roles.

A Sufi woman named Bibi Fatimah Sam has been placed in Sufi women in all significant works, and there have been various venerated sayings related to her personality. Baba Farid used to say about her prayers and devotion, that those were equal to the prayers of ten Kamil (perfect) Sufi men. Shaikh Nizam used to visit her dargah for meditation and prayers. It is narrated in Fuwad ul Fawaid that one day the Shaykh commented on the virtues of women, and he remembered Bibi Fatimah Sam. Due to her devotion and chastity, Farid ud Din repeatedly says, "that woman is a man whom the creator has sent to the earth in the bodily form of a woman." In her bodily form, a woman was not equal to a man Sufi; thus, she had to be perceived and viewed as a man to be able to find a place on the table of Sufis in the South Asian context (Abbas, 2002; Ghadially, 2005).

Similarly, in Siyar ul Awliya, Amir-Khurd (1884) had recorded a detailed description of Baba Farid's daughters, especially Bibi Sharifah. She was recalled for her piety and renunciation, but she had not passed the spiritual authority or khirqah. Baba Farid, though acknowledged her piety, did not consider her the spiritual successor. He used to say, "if it were lawful to pass on the khirqah of khilafat to females, I would have given it to my pious daughter Bibi Sharifah, if all of the women become like her, they would surpass all men" (Siyar ul Awliya: 191).

These examples demonstrate that women have been imagined and discussed in the Sufi literature in multiple and contradictory ways. To fully understand these assertions, the context and historical realities must be kept in mind. Moreover, it is also revealed that these diverse 
imaginations have also impacted the world of activity. While negative imaginations about women generally created impediments for them in realizing their full potential as human beings, positive assertions led them to pursue their path with confidence. The social-cultural context adds to social reality as in how men and women are viewed in certain cultures. Despite the gender-biased portrayal of women in many instances, the Sufis denounced genderdiscriminatory practices explicitly through their actions. The women, being capable of treading the path of the Sufi, venerated those Sufi women who earned such status due to their piety and love of the Divine.

\subsection{Gendered Social Roles of Women (as sisters, daughters, mothers, wives)}

Another evident trend from history is related to the fact that women are almost entirely presented within their gendered social roles (Roded, (1994). While the Sufi men have enjoyed access to public and private spaces alike, the Sufi women have been restricted to the private spaces only. Moreover, they were mostly allowed to interact and guide women (females) only. There are very few Sufi women who have enjoyed respect and status within Sufi circles without being associated with their male family members. These Sufi women were addressed and remembered as pious, chaste, spiritual, capable, and their fathers, brothers, husbands, or sons. Unlike male Sufis, the Sufi women are identified by their family relations primarily than their spirituality and piety. Thus, Sufi women were sisters, daughters, mothers, or some other relation in the reports on their connection to Sufism in the context of South Asia. Besides, Sufis' (men's) mothers have also received veneration and exaltation since their sons achieved the spiritual glories.

Bonouvrie (1995), in her study of female Sufi saints on the Indian Subcontinent, tried to explore the presence of Sufi women throughout the history of South Asia. Interestingly, by analysing stories related to Sufi women's lives in India, she argued that some specific images (portrays/stereotypes) reflected the shared held views and perceptions of the society towards Sufi women. She also focused on the cultural context of female saint veneration in India and argued that in the Hindu religion, the adoration of female deities has also impacted the Muslims, and therefore, the female saint veneration started. By traditional stories about five Sufi women in India, she concluded that some stereotypes could be observed in this regard. A more significant aspect of her study is that she has identified a female sainthood pattern in the Indian sub-continent that comprises certain elements. Among those, specific honorific titles are given to females (Bibi, Lalla, Shaykha, and Mai), females' social relations with the male saints (daughter, mother, sister, and wife), females being portrayed as a virgin, unmarried. However, there is no exact mentioning of the reasons why these women had to be venerated. It is interesting to note how women have gained and exercised authority in relations with Sufis within South Asia (Suvorova, 2011).

Other historical sources that contribute to understanding the women who have pursued piety (Sufism) demonstrate that those who decided to adopt the spiritual journeys were also subject to normative social constraints depending upon the societal norms and mores. Some of them lived typical lives, married, and bore children, while others lived relatively independent and free from much of the androcentric gender roles. As Ernst (1999) argued, one finds typical patterns of women's presentation that may well be explained by predictable male-female dynamics in Sufi biographies. On the issue of attaining spiritual mastery within Sufism, Shaikh (2009) argued that spiritual mastery is fundamentally connected to maleness and that the females who wanted to attain that status could only do that when they are depicted as taking 
on a male persona, which reflects the deeply patriarchal nature of the discursive field. As Silvers (2014) writes:

There is nothing inherent to women about any of these socio-historical contexts. Thus, there is little historical value in identifying 'spirituality' particular to women, unless it refers to the dynamic and intersecting socio-historical narratives that name specific types of bodies, experiences, and articulations' female' (Silvers, 2014: 28).

From the South Asian Sufi tradition, many women who were related to Sufis (as relatives) can be ascertained. These include Bibi Sara (Mother of Shaykh Nizam-al-Din), Bibi Qursum (Mother of Fariduddin Ganj-I Shakar), Princess Jahanara (Sister of Price Dara Shikuh-both were initiated in Qadari Sufi order), Bibi Rasti (Mother of Hazrat Sultan Bahu), Bibi Masturah, Bibi Fatima, Bibi Sharifah (Daughters of Baba Farid) and many more. Hazrat Sultan Bahu had great love and respect for her mother, and in his work, Mehak-ul-Faqr Kalan said, "My mother's eyes bled while invoking. I also experienced this state. It is called the Divine presence." In Akhbar ul Akhyar, three women have been mentioned in the pious women section as mothers of Sufis. Nizam ud din Abumulid's mother Bibi Sara, Shaikh Farid ud Din Ganj Shakr (not mentioning her name), and Bibi Zulekha - mother of Khawja Nizam ud din. These pious women were depicted as pious mothers and venerated since their sons attained spiritual elevations. As Schimmel (2003) points out, the mother motif is of central significance in Islam and Sufism. These women have been venerated not only by their immediate family members but also by the public in general. Concerning the Sufis, they are also considered as individuals with blessed nature. Many miracles are also attributed to them. They are always remembered and discussed with Sufis (men).

\subsection{Sufis World of Activity (South Asian Sufi Milieu)}

Another evident trend in the collected data on women and Sufism is the Sufi world of activity and women's role. Sufism in South Asia is associated with the shrines and Sufis. The shrines (spaces) are considered public spaces that are out of access for women since in most cases they are restricted to private spaces (home) only. Similarly, Sufism in South Asia has a profound impact on the society, and local culture and norms have also affected the Sufism reciprocally. Therefore, the Sufi world of activity is informed by all those values and norms that are part of the region's culture.

Rizvi (1978) asserts that female Sufis were generally discouraged in Sufi world of activity in several ways in the South Asian context. Moreover, female mystics were never incorporated into khanqas and Sufi orders as spiritual succession could not be traced through them. Often, they became hermits or lone dervishes and, often, lived without the comforts, both spiritual and material, provided by Pirs and Khanaqas. Therefore, it would not be unfair to say that Muslim women who became deeply committed to mysticism and a life of asceticism did so despite a lack of encouragement and assistance from their male counterparts (Sufi men) and Islam in general (Rizvi, 1978: 403; Helminski, 2003; Thaver, 2018).

Furthermore, the access and authority to the shrine spaces are also reserved for men and by men. Some of these norms and values reflect the gendered order of the larger society and stereotypes about women. For instance, access of women to the innermost sanctuary of some of the Sufi shrines is sometimes restricted for women based on stereotypical notions that their 
physical presence pollutes the shrine and the idea that women distract men seeking spiritual experiences in the inner chambers. Women are worldly and attract to worldly pleasures (sin); hence they should be denied entry to sacred places like Sufi shrines. The society's discriminatory treatment of women demonstrates the double standard that prevailed in the South Asian society at the time.

Another scholar, Kakkar (2006), approached Sufi women and their shrines in India and raised several questions about women's saintly authority and position. For instance, while exploring the relationship between saintly authority and women's socio-cultural roles in India, she asked a critical question if women occupy positions of significance and eminence in the Sufi hierarchical order, or did they derive their identity primarily by being mothers, sisters, daughters, or wives? (2006: 276-286). The conferring of spiritual status in Islam does not depend on gender; hence, they are viewed as equals and capable of earning the saintly authority and status, which are not ascribed (Kakkar, 2006: 277).

Women's presence and participation within Sufism in practice is more complex and required historicizing with contextual understanding. As mentioned by Sharify-Funk et al. (2017) that "considering the status of women within Sufi and Muslim contexts is not simply a matter of marginalization or "empowerment," but is far more nuanced, as women negotiate and occupy a spectrum of the sphere in their enactment of Sufi traditions"(213). Similarly, Shaikh (2012) argued that Sufism neither presents a monolithic position on gender nor "a-historical panacea for all things beneficial for women" (p. 72). Working on the Sufi authority of women in India, Pemberton (2006) analysed women's spiritual authority and saintly succession in these words: "In matters of spiritual authority and saintly succession, the ceremonial investiture of women as spiritual guides is a contested practice in the world of mainstream Sufi orders and Shrines" (Pemberton, 2006: 66). Women's role and status within a society are informed by cultural and traditional norms and popular religious discourses. As noted earlier, some pre-modern Islamic discourses have marginalized women as deficient in intellect and religion and relegated most women to the private sphere (household and gender roles). As a result, Sufi women did not occupy public leadership roles in the more institutionalized forms of Sufi practice" (SharifyFunk et al., 2017: xx; Birchok, 2016).

\section{Conclusion}

In some ways, history accepts that women have played a significant role in Sufism, however, not just as mothers to the Sufis but had inspired many as spiritual teachers and guides. However, with time, the Sufi women became invisible or erased from the mainstream Sufi discourse and activity. There have been many factors and reasons behind this erasure of the Sufi women. Nevertheless, one of the significant aspects is the prevalence of Purdah or veiling in the Muslim societies. The concept of Purdah is associated with women that discourage the women's visibility in the public spheres reserved for men. They are also not the most talked about subject in the male-dominated spaces since society and religion both prohibit it in the South Asian context. Women's absence from mainstream activity has affected their presentation in Sufism as well. From the formative times until contemporary modern society, women remained equally committed to Sufism's path but did not receive the due attention from the hagiographers and historiographers.

Like other women in the mainstream Islam, there is not much written evidence regarding the Sufi women in the official documents, and standard texts in Sufism. Nevertheless, the historical 
evidence has preserved several names of ascetic and Sufi women who witnessed Islamic mysticism's feminine side (Elias, 1998). Scattolin (1993) presents that Ibn al-Jawzi (d. 1200) has recorded details of more than two hundred Sufi women. He declares that most of these women lived during the first and second generations of Islam. Names of later Sufi women are rare. Scattolin questions if this is a sign of Muslim women's decreasing status over time (Scattolin, 1993: 198). There is ample evidence supporting women association with Sufism, especially with shrines complex in the South Asian milieu. However, one should always be careful of making any general claims related to the women's role within Sufism. The women's presence and participation within Sufism is more complex and requires historicizing with contextual understanding.

The issue of gender and women remained central to the debates on Islam in general and the Sufism in particular. At levels of discourse and activity, Sufism offered much space to women and accommodated the gendered beings, including the transgender community. Sufis's conception of Insan-i-Kamil (perfect human being) and Waliullah (friends of Allah) constitute a diverse spectrum of imaginations, consequently impacting the social world of activity. These "Sufi conceptualization of complete or perfect human being imply a state in which Jalal (masculine) and Jamal (feminine) qualities become integrated" (Sharify-Funk, 2017: 189). Therefore, the gender/women remained a highly significant trend/theme and occupied a central focus within the Sufism.

By and large, the historical trends show that women within the Sufi thought and activity had been situated marginally. These trends reflect the specific socio-cultural context and the popular discourses, which are evident in women's position and status in the religious and spiritual domains, including Sufism in South Asia. Since Sufi women are less celebrated in the scholarly literature, as evident from the available sources in the history of Sufism in South Asia, more research studies could highlight the crucial aspects of gender and Sufi thought to clear the fog. Further investigation of silencing or erasing women from the Sufi activity is also crucial because many Sufis (male) used the feminine pronouns while explaining their relationship with the Divine in the poetry. Similarly, more historical evidence is needed to unearth this region's socio-cultural dynamics while considering the gender hierarchies in Sufi thought and activity.

\section{References}

Abbas, S. B. (2002). The female voice in Sufi ritual: devotional practices of Pakistan and India ( $1^{\text {st }}$ ed.). University of Texas. https://utpress.utexas.edu/books/abbfem

Amir-Khurd, Muhammad Mubarak Kirmani 'Alawi. (1884). Siyar al-awliya dar ạ̣wal va malfuzat-i mashayikh-i-Chisht (ed.), Chiranji Lal. Mohibb-i Hind Press.

Austin, R. W. (2007). Sufis of Andalusia: the Ruh al-Quds and al-Durat Fakhirah of Ibn'Arabi. Routledge.

Azad, A. (2003). Female mystics in Medival Islam: a quiet legacy. Journal of the Economic and Social History of the Orient, 56(1), 53-88. http://doi.org/10.1163/15685209$\underline{12341277}$

Birchok, D. (2016). Women, genealogical inheritance, and Sufi authority: the female saints of Seunagan, Indonesia. Asian Studies Review, 40(4), 583-599. https://doi.org/10.1080/10357823.2016.1224999

Bonouvrie, N. (1995). Female Sufi saints on the Indian Subcontinent. In R. Kloppenborg, and 
W. J. Hanegraaff (Eds.), Female stereotypes in religious traditions (109-122). Brill. https://brill.com/view/book/edcoll/9789004378889/BP000007.xml

Buehler, A. F. (2016). Recognizing Sufism: contemplation in the Islamic tradition. I. B Taurus. https://www.goodreads.com/book/show/33026658-recognizing-sufism

Callan, A. (2008 ). Female saints and the practice of Islam in Sylhet, Bangladesh. American Ethnologist, 35(3), 396-412. https://doi.org/10.1111/j.1548-1425.2008.00042.x

Cornell, R. E. (1999). Early Sufi women (Dhikr an-niswa al-muta'abbidat as-Sufiyyat) by Abu 'Abd ar-Rahman as-Sulami. Fons Vitae. https://www.amazon.com/Early-SufiWomen-Niswa-al-Mutaabbidat/dp/1887752064

Dakake, M. M. (2002). Walking upon the path of God like men?: women and the feminine in the Islamic mystical tradition. Sophia: A Journal of Traditional Studies, 8(2), 131151. http://www.worldwisdom.com/uploads/pdfs/64.pdf

Elias, J. J. (1998). Female and feminine in Islamic mysticism. Muslim World, 78 (July October),

209-224. https://www.academia.edu/876770/Female_and_Feminine_in_Islamic_Mysticism

Ernst, C. W. (1997). The Shambhala guide to Sufism. Shambhala.

Ernst, C. W. (2003). Between orientalism and fundamentalism: problematizing the teaching of Sufism. In B. M. Wheeler (Ed.). Teaching Islam (pp. 108-123). Oxford University.

Ernst, C. W. (2009). Sufism, Islam, and globalization in the contemporary world: methodological reflections on a changing field of study. The Fourth Victor Danner Memorial Lecture. Department of Near Eastern Languages, Indiana University. https://www.academia.edu/4416963/Sufism_Islam_and_Globalization_in_the_Cont emporary_World_Methodological_Reflections_on_a_Changing_Field_of_Study

Flueckiger, J. (2006). In Amma's healing room: gender and vernacular Islam in South India. Indiana University.

Frede, B., \& Hill, J. (2014). Introduction: engendering Islamic authority in West Africa. Islamic Africa, 5(2), 131-165. https://doi.org/10.5192/215409930502131

Gemmeke, A. (2009). Marabout women in Dakar: creating authority in Islamic knowledge. Africa: The Journal of the International African Institute, 79(1), 128-147. https://www.jstor.org/stable/29734394

Ghadially, R. (2005). Devotional Empowerment: women Pilgrims, saints and shrines in a South Asian Muslim Sect. Asian Journal of Women's Studies, 11(4), 79-101. https://doi.org/10.1080/12259276.2005.11666001

Helminski, C. (2003). Women of Sufism: a hidden treasure: writings and stories of mystic poets, scholars \& saints $\left(1^{\text {st }}\right.$ Ed. $)$. Shambhala.

Hill, J. (2010). 'All Women are guides': Sufi leadership and womanhood among Taalibe Baay in Senegal. Journal of Religion in Africa, 40(4), 375-412. https://doi.org/10.1163/157006610X540735

Hill, J. (2014). Picturing Islamic authority: gender metaphors and Sufi leadership in Senegal. Islamic Africa, 5(2), 275-315. https://doi.org/10.5192/215409930502275

Hill, J. (2018). Wrapping authority: women Islamic leaders in a Sufi movement in Dakar, Senegal. University of Toronto. https://utorontopress.com/us/wrapping-authority-2

Kakkar, J. (2006). Sufism and women: A note on two women Sufis and their Dargahs at Delhi. In S. Z. Hussain Jaferi, \& H. Reifeld (Eds.), The Islamic path: Sufism, society, and Politics in India (pp. 276-286). Rainbow.

Kasmani, O. (2016). Women [un-]like women: the question of spiritual authority among female fakirs of Sehwan Sharif. In M. Boivin, \& R. Delage, Devotional Islam in contemporary South Asia: shrines, journeys, and wanderers (pp. 47-62). Routledge. 
Knysh, A. (2017). Sufism: a new history of Islamic mysticism. Princeton University.

Kim, S. (2009). A Sufi approach to issues of gender and reconciliation. St. Francis Magazine Nr, Vol. V. http://www.stfrancismagazine.info/ja/content/view/229/38/

Nurbakhsh, J. (2004). Sufi women. Khaniqahi Nimatullahi. https://www.nimatullahi.org/sufiwomen/

Pande, R. (2010). Divine sounds from the heart-singing unfettered in their own voices: the Bhakti movement and its women saints (12 th to $17^{\text {th }}$ Century). Cambridge Scholars.

Pemberton, K. (2006). Women Pirs, Sainlty Succession, and Spiritual Guidance in South Asian Sufism. The Muslim World, 96, 61-87. https://doi.org/10.1111/j.14781913.2006.00118.x

Pemberton, K. (2016). The Politics of gender in Sufi imaginary. In D. Dandekar, \& T. Tschacher, Islam, Sufism and Everyday Politics of Belonging in South Asia (pp. 103121). Routledge.

Raudvere, C. (2002). The book and the roses: Sufi women, visibility, and zikir in contemporary Istanbul (transactions, v. 12). Swedish Research Institute in Istanbul.

Rizvi, S. A. (1978-83). History of Sufism in India (two volumes). Manoharlal.

Roded, R. (1994). Women in Islamic biographical collections: from Ibn Sa 'd to who's who. L. Rienner.

Scattolin, G. (1993). Women in Islamic mysticism in encounter: documents for Muslim Christian understanding. (J. L. Balda, Ed.) Encounter.

Schimmel, A. (2003). My soul is a woman: the feminine in Islam. Bloomsbury Academic.

Schimmel, A. (2019). Sufism. Encyclopedia Britannica. https://www.britannica.com/topic/Sufism

Shafiq, S. \& Rehman, A. U. (2018). Land, conflict and traditional institutions in the NorthWest Pakistan: an appraisal of Hazarkhwani, Peshawar. Journal of the Punjab University Historical Society, 31(1), 235-246. http://pu.edu.pk/images/journal/HistoryPStudies/PDF_Files/22_V-31-No1$\underline{\text { Jan18.pdf }}$

Shaikh, S. (2009). In Search of al-Insān: Sufism, Islamic Law, and Gender. Journal of the American Academy of Religion, 77(4), 781-822. https://doi.org/10.1093/jaarel/lfp052

Shaikh, S. (2012). Sufi narratives of intimacy: Ibn Arabi, gender, and sexuality. The University of North Carolina.

Sharify-Funk, M., Dickson, R. W., \& Xavier, M. S. (2017). Contemporary Sufism: piety, politics, and popular culture. Routledge.

Silvers, L. (2014). Early pious, mystic Sufi women. In L. Ridgeon (Ed.), The Cambridge companion to Sufism (Cambridge Companions to Religion, pp. 24-52). Cambridge University. https://doi.org/10.1017/CCO9781139087599.004

Smith, B. J. (2014). When wahyu comes through women: female spiritual authority and divine revelation in mystical groups and pesantren - Sufi orders. In B. J. Smith, \& M. Woodward, Gender and power in Indonesain Islam: leaders, feminists, Sufis and pesantren selves (pp. 83-103). Routledge. http://hdl.handle.net/11343/111969

Smith, M. (1928). Rabi 'a the mystic \& her fellow-saints in Islam; being the life and teachings of Rabi 'a al-'Adawiyya al-Qaysiyya of Basra together with some account of the place of the women saints in Islam. Cambridge University.

Smith, M. (2001). Muslim women mystics: the life and work of Rabi 'a and other women mystics in Islam. Oneworld. https://www.jstor.org/stable/27933896

Suvorova, A. (2011). Muslim saints of South Asia: the eleventh to fifteenth centuries. Routledge 
Thaver, T. (2018). Beauty and light: mystical discourses by a contemporary female Sufi master. Fons Vitae.

Tryckeri, B. \& Schielke, S. (2008). Mystic states, motherly virtues, female participation and leadership in an Egyptian Sufi milieu. Journal of Islamic Studies, 28(1), 94-126. https://journals.co.za/doi/10.10520/EJC48330

Widiyanto, S. (2014). Reframing the gendered dimension of Islamic spirituality: silsilah and the 'problem' of female leadership in tarekat. In B. J. Smith, \& M. Woodward, Gender and power in Indonesian Islam: leaders, feminists, Sufis and pesantren selves (pp. 103-117). Routledge. http://hdl.handle.net/11343/111969

\section{Notes:}

${ }^{1}$ Tabaqat is a significant part of Sufi literature documenting the lives and works of Sufis. It includes section on Sufi women (5) in India.

2 Silsila is an Arabic word that refers to genealogical order/chain of Sufis, saints, and mystics.

${ }^{3}$ Arabic term, which literally means someone who wears wool. The term refers to the Sufis and mystics metaphorically.

${ }^{4}$ There have been many Sufi women Shaykhas recognized in different Sufi orders in recent times Cf. Shaykha Fariha Fatima al Jerrahi, Shaykha Cemula SargutNur, Shaykha Oumou Malick, Shakyha Nahid Angha, Shaykha H Nur Artiran, Shaykha Devi Tide.

5 Emphasis added.

${ }^{6}$ Hagiography - a specific genre of literature that entails the biographical works on saints, Sufis and mystics.

${ }^{7}$ Emphasis added. 